\title{
Analisis SWOT Dalam Persiapan Pemberdayaan Sosial Komunitas Adat Terpencil
}

\section{Rd Siti Sofro Sidiq ${ }^{*}$}

${ }^{1}$ Universitas Riau, Indonesia

\section{A R T I C L E I N F O}

Article history:

Received 23 Agustus 2020

Accepted 10 Desember

2020

Available online 31

Desember 2020

Kata Kunci: Analisis SWOT; Pemberdayaan Sosial;

Komunitas Adat Terpencil;

Desa Sonde

Keywords:

SWOT analysis; Social

Empowerment; Remote

Indigenous Community;

Sonde Village

\begin{abstract}
A B S T R A K
Perkembangan pemberdayaan KAT masih terbilang cukup kurang dan belum mampu membuat masyarakat mandiri serta keluar dari garis kemiskinan. Salah satu penyebabnya adalah dalam hal analisis persiapan pemberdayaan yang akan menentukan arahan kebijakan dan tahapanan pemberdayaan KAT. Tujuan dari penelitian ini menjelaskan secara komprehensif bagaimana analisis swot dalam mempersiapkan pemberdayaan sosial Komunitas Adat Terpencil di Desa Sonde, Metode yang digunakan ialah deskripsitif kualitatif untuk menjelaskan dan menggambarkan pengumpulan data menggunakan studi kepustakaan dengan pendekatan induktif, pengamatan terlibat, wawancara mendalam, pembelajaran masyarakat pedesaan secara partisipatif, dan diskusi kelompok terfokus (focus group discussion) dengan masyarakat adat, tokoh adat serta pemangku kebijakan. Hasil penelitian menunjukkan bahwa Desa Sonde memiliki potensi sumber daya alam dan manusia yang cukup memadai yaitu demografi penduduk dalam usia produktif serta tanah pertanian yang cukup luas dalam bentuk tanah belukar. Tantangannya adalah terwujudnya prioritas pemberdayan lingkungan,
\end{abstract} pemberdayaan sumber daya manusia, pemberdayaan ekonomi produktif serta penataan perumahan dan pemukiman. Analisis Swot digunakan untuk mempersiapkan program pemberdayaan di Desa Sonde yang bertujuan untuk memberikan peluang sinergi lintas sektor dalam setiap tahapan persiapan sehingga ditemukan prioritas pemberdayaan, dan alternative solusi bagi permasalahan tersebut.

\section{A B S T R A C T}

The development of KAT empowerment is still quite lacking and has not been able to make the community independent and out of the poverty line. One of the causes is in terms of empowerment preparation analysis which will determine the policy direction and stages of KAT empowerment. The purpose of this research is to explain comprehensively how SWOT analysis is in preparing for social empowerment of Remote Indigenous Communities in Sonde Village. The method used is descriptive qualitative method to explain and describe data collection using studies literature with an inductive approach, involved observation, interviews in-depth, participatory learning of rural communities, and focus group discussions with indigenous peoples, traditional leaders and policy makers. The results showed that Sonde Village has sufficient natural and human resource potential, namely the demographics of the population in productive age and large agricultural land in the form of scrub land. The challenge is the realization of environmental empowerment priorities, human resource empowerment, productive economic empowerment and housing and settlement arrangement. Swot analysis is used to prepare empowerment programs in Sonde Village which aim to provide opportunities for cross-sector synergies in every preparation stage so that empowerment priorities are found, and alternative solutions to these problems.

Copyright (c) Universitas Pendidikan Ganesha. All rights reserved.

\footnotetext{
* Corresponding author.

E-mail addresses: sitisofrosidiq@lecturer.unri.ac.id
} 


\section{Pendahuluan}

Persiapan pemberdayaan komunitas adat terpencil menjadi salah satu syarat untuk mempersiapkan program-program yang sesuai dengan kebutuhan dari daerah tersebut, Komunitas adat terpencil dibagi menjadi beberapa kelompok atau etnik serta ditemukan di hampir seluruh bagian negara baik yang berada di pegunungan maupun telah menetap di daerah pesisir. Komunitas Adat Terpencil menurut Peraturan Presiden Republik Indonesia nomor 186 tahun 2014 tentang pemberdayaan sosial terhadap komunitas adat terpencil, adalah sekumpulan orang dalam jumlah tertentu yang terikat oleh kesatuan geografis, ekonomi, dan/atau sosial budaya, dan miskin, terpencil, dan/atau rentan sosial ekonomi. Meskipun demikian, komunitas adat terpencil terkenal sebagai sektor termiskin di negara (Batangan et al, 2007; United Nations, 2002; Davis and Patridge, 1994; Plant, 2002; McCaskill and Kampe, 1977; Singh and Jabbi, 1996). Situasi tersebut telah disadari secara universal di deklarasi PBB mengenai hak masyarakat adat (UNDRIP) dan UndangUndang Hak Masyarakat Adat (IPRA) yang mencakup hak dari masyarakat adat dan usaha yang seharusnya diambil untuk memastikan bahwa haknya terpenuhi.

Namun demikian menurut para ahli kondisi yang demikian hanyalah seperti sebuah kontrak antara ilmuwan dengan sasaran pemberdayaan karena bagaimanapun juga desain dan manajemen masih dikendalikan sepenuhnya oleh inisiator pemberdayaan sehingga hasilnya adalah nol atau hanya sebuah kamuflase (Cornwall and Jewkes, 1995). Situasi ini pernah terjadi di komunitas Aborigin di wilayah bagian tenggarayang menderita dalam beberapa aspek karena penelitian yang melelahkan. Hasilnya adalah hanya beberapa keuntungan yang bias didapatkan dari penelitian tersebut (Campbell \& Christie, 2008).

Maka dari itu penting untuk menyadari dan mempertimbangkan intervensi yang seharusnya fokus dan memastikan program yang diimplementasikan di komunitas adat terpencil. Pada dasarnya pemberdayaan komunitas adat terpencil adalah untuk memperbaiki kualitas dan kesejahteraan sosial dari komunitas-komunitas tersebut. Target dari implementasi program pemberdayaan tersebut adalah komunitas adat terpencil yang berada di area terpencil, tertinggal dan terisolir dari aspek sosial, budaya, dan ekonomi terutama sumber daya manusia, dan secara geografis mengalami kendala dalam memperoleh layanan kebutuhan dasar (Ministry of Social Republic of Indonesia, 1: 2015).

Berkaitan dengan hal tersebut, Indonesia telah mempunyai peraturan undang-undang no 39 tahun 2012 tentang implementasi kesejahteraan sosial yang diikuti dengan dikeluarkannya Peraturan Presiden No. 186 tahun 2014 tentang pemberdayaan sosial di komunitas adat terpencil. Ditandatanganinya peraturan tersebut menunjukkan bahwa permasalahan tentang KAT perlu membutuhkan perhatian khusus dan masih perlu untuk diberdayakan. Terdapat dua alasan utama mengapa komunitas adat terpencil perlu untuk diberdayakan, yaitu 1) keterpencilan geografis, dan 2) ketahanan negara.

Dari hasil penelitian 2017, memiliki keunikan dan pertimbangan dalam hal pembangunan di Komunitas Adat Terpencil, yaitu: 1) berkaitan dengan ketahanan negara karena desa ini terletak di daerah pesisir yang berbatasan dengan selat Malaka. Selat Malaka merupakan perbatasan antara Indonesia dengan Malaysia sehingga desa Sonde memerlukan perhatian khusus terutama kesejahteraan social, 2) keterpencilan geografis. Jarak desa Sonde ke pusat pemerintahan adalah sekitar $123 \mathrm{~km}$ dengan waktu tempuh sekitar 9 jam dengan berganti-ganti mode transportasi baik melalui jalur laut maupun darat. Kondisi tersebut diperparah dengan banyaknya kondisi jalan yang rusak yang mengakibatkan desa Sonde semakin sulit untuk diakses, 3) lambatnya pertumbuhan ekonomi. Keterpencilan geografis menyebabkan roda perekonomian di desa Sonde berputar di sektor pertanian, peternakan dan perikanan yang terbatas dengan menggunakan teknologi yang masih sederhana sehingga kesejahteraannya masih dibawah standar. Hal ini juga tercermin dari bangunan fisik rumah yang tidak layak huni serta peralatan memasak yang sangat terbatas.

Aspek lainnya adalah, 4) kualitas sumber daya manusia. Tidak hanya kesejahteraan ekonomi yang rendah, tingkat pendidikan yang dimiliki oleh warga Sonde juga masih jauh dari 
standar yang disebabkan oleh akses pendidikan dan fasilitas bangunan sekolah yang tidak memadai, 5) derajat kesehatan. Tingkat kesehatan warga Sonde masih dalam taraf sangat penting untuk ditingkatkan dilihat dari kesehatan tempat tinggal mereka yang belum memenuhi syarat karena pembagian ruangan yang tumpang tindih seperti dapur dengan kamar tidur, tempat buang air besar, dan juga penggunaan air bersih baik untuk minum, mandi maupun aktifitas lain. Sedangkan untuk pos dan layanan kesehatan, tempatnya jauh dari jangkauan warga.

Fase persiapan pemberdayaan merupakan aspek yang paling penting dari 4 tahapan pemberdayaan sosial komunitas adat terpencil, yaitu a) persiapan pemberdayaan, b) pelaksanaan pemberdayaan, c) rujukan, dan d) terminasi. (Anggreswari \& Jayaningsih, 2018) menjelaskan bahwa setiap pemberdayaan memiliki tujuan untuk menyadrkan masyarakat tentang keberadaan suatu program sehingga masyarakat akan mengerti tentang peningkatan kemampuan untuk mandiri. Sedangkan (Rahim, Tahir, \& Rumbia, 2014)memberikan definisi tujuan utama dari pemberdayaan adalah untuk memotivasi orang terhadap sebuah perubahan dalam keseharian mereka dan juga terhadap kehidupan yang lebih baik berdasarkan nilai-nilai yang berbeda dari komunitas adat terpencil yang berakar secara kuat di institusi sosial, sehingga nilai baru yang dibawa harus sejalan dengan nilai-nilai yang telah ada untuk menciptakan harmoni dan akulturasi yang baik dengan tradisi yang telah ada. Membawa nilai-nilai yang bertentangan dengan tradisi dan sistem sosial budaya yang telah diterapkan akan memicu pada penolakan yang pada akhirnya hanya akan menimbulkan kegagalan dalam mencapai tujuan dan mengimplementasikan aktifitas program.

Sejalan dengan pendapat Suyanto \& Mujiyadi (2015: 18), pemberdayaan KAT masih sangat lambat dan belum mampu membuat masyarakat mandiri dan keluar dari garis kemiskinan. Terdapat tiga alasan yang mendasarinya, yaitu 1) kurangnya sinergitas stake holder dalam program pemberdayaan KAT, 2) dalam proses implementasinya, fasilitas yang diberikan seringkali meninabobokan KAT dan tidak menjadikan masyarakat yang mandiri dan berdikari, 3) kebijakan yang digunakan kadang juga bersifat topdown yang kurang melibatkan masyarakat dalam tahapan pemberdayaan sosial masyarakat terutama dalam fase persiapan sehingga sering terjadi penolakan ataupun keberhasilan yang semu. Mengacu pada penjelasan diatas, maka artikel ini akan membahas bagaimana analisis SWOT dalam persiapan pemberdayaan sosial di Desa Sonde Kecamatan Rangsangan Pesisir Kabupaten Kepulauan Meranti.

\section{Metode}

Penelitian ini menggunakan metode kualitatif yang bertujuan untuk menggambarkan dan mendeskripsikan seluruh subjek penelitian secara holistic dan komprehensif, subjek penelitian adalah tokoh adat, stakeholder terkait yang akan mempengaruhi pesiapan pemberdayaan komunitas adat terpencil. Pengumpulan data dilakukan untuk mendapatkan data-data kekuatan, peluang, tantangan dan hambatan dari desa, sehingga menjadi acuan untuk proses persiapan pemberdayaan, maka dari itu dengan melakukan 1) studi kepustakaan dengan pendekatan induktif (literature study inductive approach.), 2) pengamatan terlibat (participatory observatory), 3) wawancara mendalam( in-depth interview), 3) pembelajaran masyarakat pedesaan secara partisipatif (participatory rural approach), 4) diskusi kelompok terfokus (focus group discussion).

Data yang telah diperoleh dianalisis dengan menggunakan tiga pendekatan, yaitu 1) pendekatan budaya. Pendekatan budaya melihat warga KAT yang menjadi sasaran pengkajian sebagai inidividu-individu yang memahami dan memanfaatkan serta memperdayakan berbagai sumber daya yang ada dilingkungan sekitar baik secara fisik maupun sosial supaya dapat mempertahankan dan meningkatkan kesejahteraan hidup, 2) pendekatan holistik yaitu warga KAT yang menjadi sasaran studi kelayakan dilihat dalam berbagai aspek kehidupan, dan penghidupan 
perlu mendapatkan dukungan pengembangan dari berbagai sektor terkait serta pemerintah daerah dalam rangka meningkatkan kualitas hidup warga tersebut, dan 3) pendekatan sistemik. Pendekatan ini memposisikan warga KAT sebagai satu kesatuan yang utuh yang tidak terpisahkan satu sama lain dan menyeluruh sebagai sasaran pokok dalam studi kelayakan. Dalam hal ini warga KAT saling berinteraksi dengan tim, sehingga mendapatkan dukungan penuh dari berbagai sektor terkait dan dari pemerintah daerah dalam rangka peningkatan kuliatas kehidupan sebagai sasaran kajian.

\section{Hasil dan Pembahasan}

Berdasarkan temuan data geografis, demografis serta deskripsi kehidupan ekonomi, sosial dan budaya di bagian sebelumnya, Desa Sonde termasuk dalam Komunitas Adat Terpencil (KAT) karena aspek keterpencilan geografis, berada di daerah pesisir, dan kesulitan mendapatkan akses layanan pemenuhan kebutuhan dasar serta pelayanan administrasi. Desa Sonde mayoritas penduduknya adalah suku Akit sebagai suku asli. (Hasbullah, 2018) menjelaskan bahwa desa sonde disebut sebagai Masyarakat suku Akit yang tidak mudah menerima sesuatu yang baru. Mereka memiliki sikap tertutup dan tetap mempertahankan tradisi nenek moyangnya. Bahkan dari segi keyakinan mereka masih menganut paham animisme dan dinamisme.

Merujuk pada data yang sama pula, hasil penelitian 2017 serta pendapat dari (Sidiq \& Sulistyani, 2017) bahwa peluang dan tantangan dari pemberdayaan komunitas adat terpencil adalah tentang paham kebudayaan, maka dari itu akan membahas kekuatan, kekurangan, peluang, dan ancaman yang dimiliki oleh desa Sonde serta kebijakan dan tindakan yang akan diambil dengan merujuk pada analisis SWOT seperti terlihat pada Tabel 1.

Tabel 1. Analisis SWOT

\begin{tabular}{|c|c|}
\hline Strengths & Weaknesses \\
\hline $\begin{array}{l}\text { - Warga pada umumnya memiliki tanah } \\
\text { dari tanah adat. } \\
\text { - Lokasi mudah dijangkau walau dengan } \\
\text { - jalan setapak. } \\
\text { - Potensi alam sangat mendukung, walau } \\
\text { - Dukungan kepala desa sangat kuat } \\
\text { - Orang tua memiliki keinginan yang kuat } \\
\text { untuk menyekolahkan anaknya }\end{array}$ & $\begin{array}{ll}\text { - } & \text { Kondisi rumah tidak layak huni } \\
\text { - } & \text { Ekonomi keluarga sangat lemah } \\
\text { - } & \text { Pemukiman bersifat alami } \\
\text { - } & \text { Penghasilan kepala keluarga tidak tetap dan } \\
\text { - } & \text { relatif kecil } \\
\text { - } & \text { Pendak mempunyai jalan yang layak } \\
& \text { Pendikang tua rata rata buta huruf }\end{array}$ \\
\hline Opportunities & Threats \\
\hline 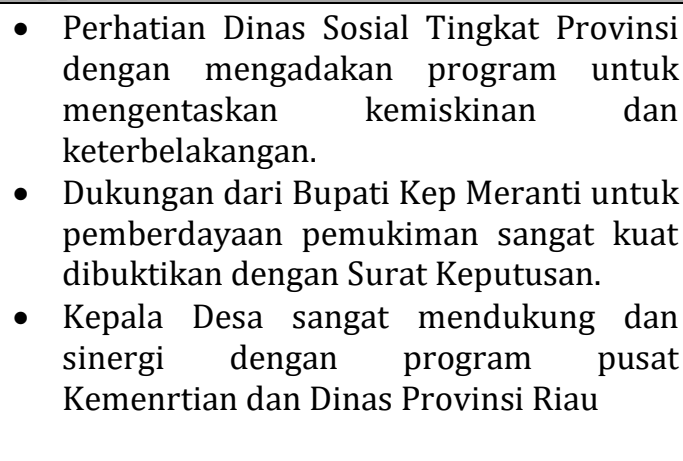 & $\begin{array}{l}\text { - Lokasi Komunitas Adat Terpencil desa Sonde } \\
\text { yang berada di Dusun } 3 \text { terancam untuk } \\
\text { tergeser. } \\
\text { Penggunaan transportasi roda 4, roda } 2 \text { dan } \\
\text { armada laut, termasuk jalan setapak untuk } \\
\text { menjangkau lokasi } \\
\text { - } \quad \text { Anggaran Terbatas. } \\
\text { - Bahan baku untuk pemberdayaan pembuatan } \\
\text { rumah didatangkan dari luar pulau. } \\
\text { - Sulit untuk mencari pekerja bangunan untuk } \\
\text { membangun rumah. }\end{array}$ \\
\hline
\end{tabular}

Sumber: Hasil Penelitian, 2017 


\section{Strengths}

Semua warga memiliki hak atas tanah mereka sendiri, hal ini memudahkan untuk pemerintah pusat memberikan bantuan seperti renovasi rumah layak huni, disisi lain potensi kekuatan yang ada ialah luas wilayah yang berdekatan dengan pesisir pantai selat Melaka sehingga masyarakat bisa memanfaatkan potensi alam berupa perikanan. Tetapi hasil temuan dilapangan menjelaskan bahwa Rincian dari luasnya lahan pertanian, varietas tanaman dan komoditi serta jumlah rata-rata produksi per tahun adalah sebagai berikut.

Tabel 2. Tanaman dan Komoditi

\begin{tabular}{|l|l|l|l|l|l|}
\hline No & Plant & $\begin{array}{l}\text { Total of } \\
\text { Land }\end{array}$ & $\begin{array}{l}\text { Number } \\
\text { of Trees }\end{array}$ & $\begin{array}{l}\text { Average } \\
\text { Production }\end{array}$ & Price/rupiah \\
\hline 1 & Sago & 290.89 & 10700 & 3210 & 9.630 .000 .000 \\
\hline 2 & Rubber & 69875 & 120750 & 7 & 70.000 .000 \\
\hline 3 & Coconut & 604.70 & 84560 & 3002 & 392.600 .000 \\
\hline 4 & Areca But & 12,06 & 540 & 1620 & 972.000 \\
\hline 5 & Durian & 857 & 216 & 10800 & 108.000 .000 \\
\hline 5 & Mangosteen & 6,4 & 178 & - & - \\
\hline 7 & Cempedak & 2,1 & 120 & 2400 & 16.000 .000 \\
\hline
\end{tabular}

Sumber :Hasil Penelitian 2017

Tabel 2 mendeskripsikan bahwa Sagu merupakan komoditas utama pertanian karena harganya yang mahal serta jumlah produksinya yang mencapai 3.210 ton/tahun. Komoditas yang juga mempunyai harga tinggi adalah kelapa dengan hasil produksi 3.002/tahun. Selanjutnya adalah karet, dan untuk tanaman yang ada tapi belum menghasilkan adalah manggis.

Sedangkan untuk peternakan, hewan yang paling produktif dan berkontribusi terhadap penghasilan warga adalah ayam dengan jumlah yang dimiliki mencapai 1300 ayam, kemudian bebek sekitar 46 ekor/ dan juga sapi yang mencapai 34 ekor. Adapun hasil dari perikanan yang paling banyak adalah ikan dengan hasil panen 46.800 ton/tahun sebagaimana terlihat pada Tabel 3.

Tabel 3. Jenis Ternak

\begin{tabular}{|l|l|l|}
\hline No & Jenis Ternak & Jumlah Ternak \\
\hline 1 & Sapi & 34 \\
\hline 2 & Kambing & 15 \\
\hline 3 & Ayam Kampung & 1300 \\
\hline 4 & Udang & 2,5 Ton /tahun \\
\hline 5 & Ikan & $46,800 /$ Ton Pertahun \\
\hline
\end{tabular}


Dari hasil diatas, dapat disimpulkan bahwa kekuatan desa sonde terletak di aspek lahan pertanian, tokoh masyarakat yang mendukung serta lokasi yang mudah dijangkau. Marwanti \& Astuti (2012) berpendapat bahwa pertanian akan menjadi sektor yang paling membantu dalam proses pemberdayaan sehingga masyarakat lebih muda mendapatkan akses untuk mengembangkannya.

\section{Weaknesses}

Kelemahan dari persiapan pemberdayaan sosial di Desa Sonde adalah Kurangnya akses ekonomi dan pendidikan sehingga taraf pendidikan masih jauh dari kata layak, hal ini dibuktikan dari hasil penelitian.

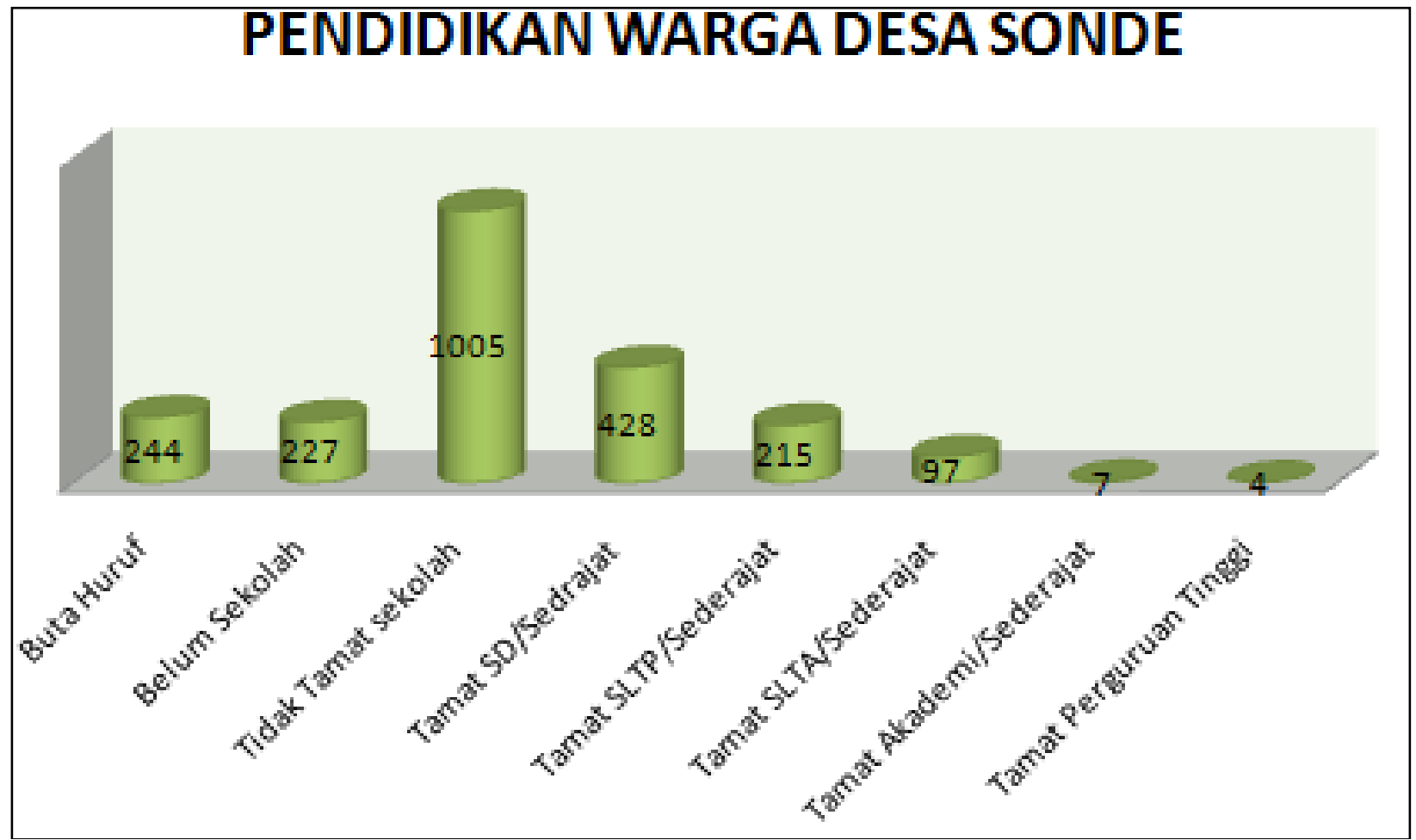

Gambar 1. Tingkat Pendidikan Warga Desa Sonde

Rendahya tingkat pendidikan yang dimiliki oleh warga desa Sonde disebabkan oleh minimnya jumlah sekolah yang dimiliki serta persebarannya yang tidak merata. Bangunan sekolah tidak terdapat di dusun 3 desa Sonde, sehingga anak-anak yang ingin bersekolah harus menempuh 4-8 km sedangkan orang tua rata-rata buta huruf. Ketiadaan sekolah tingkat menengah atas (SMA) menjelaskan bahwa pendidikan masyarakat memang harus ditingkatkan meskipun fasilitas pendidikan yang tersedia sebenarnya sudah memenuhi standar 9 tahun wajib belajar.

Untuk jenis pekerjaan dan ekonomi warga desa sonde, penduduk desa Sonde juga memiliki usaha ekonomi kreatif berupa pembuatan sagu rendang, anyaman tikar pandan, dan kerajinan atap. Sedangkan untuk industry kilang sagu dan arang meskipun julahnya masih minim namun industry ini mampu menyerap tenaga kerja dalam jumlah yang lumayan banyak sehingga beberapa penduduk juga berprofesi sebagai pekerja atau buruh baik di industri kecil, sedang maupun 
industri rumah. Sedangkan di dusun tertentu beberapa penduduk bermata pencarian sebagai nelayan mengingat desa Sonde berada di daerah pesisir yang dikelilingi oleh sungai.

\section{Opportunities}

Hadirnya peluang dari persiapan pemberdayaan komunitas adat terpencil adalah stakeholder seperti dinas sosial provinsi yang membantu dan memfasilitasi seluruh lintas sektor untuk bersama-sama ikut serta dalam persiapan pemberdayaan di Desa Sonde, akademisi berperan untuk memberikan identifikasi awal sehingga program pemberdayaan sosial bisa tepat saasaran, dibantu oleh pemerintah daerah untuk mengimplementasikan program tersebut. Pemerintah pusat dengan bantuan dana nya akan memberikan supervisi sesuai tupoksi yang telah ada.

\section{Threats}

Ada tiga lokasi yang menjadi ancaman dan membuat program ini sulit berkembang. Tiga dusun tersebut harus menggunakan beberapa alat transportasi untuk mencapai tujuan. Anggaran terbatas dari pusat membuat pasokan bahan baku untuk pembuatan rumah menjadi halangan, bahan baku harus didatangkan ibu kota setempat yang memakan waktu cukup lama dan biaya cukup tinggi serta sulit untuk mencari pekerja bangunan untuk membangun rumah.

Berdasarkan analisis SWOT, Desa Sonde sangat potensial untuk dapat diberdayakan dengan baik karena warga mempunyai hak untuk menggunakan dan memiliki lahan yang mereka tempati meskipun belum ada hak kepemilikan yang legal dari Badan Pertanahan Nasional. Ditambah lagi dengan kekayaan sumber daya alamnya, penduduk dapat mengolah, mengelola dan mengatur sumber daya tersebut guna menyiasati kecilnya dan tidak menentunya pendapatan yang diperoleh sehingga dapat memperbaiki perekonomian keluarga.

Dukungan dari kepala desa serta tingginya perhatian yang diberikan oleh Departemen Sosial Provinsi Riau juga merupakan kekuatan yang mampu mempercepat dan menjamin suksesnya program pemberdayaan sosial karena terdapat sinergi dari atas hingga ke bawah. Meskipun demikian, upaya ini juga perlu didukung dengan adanya keadaan jalan yang lebih baik karena mayoritas dari jalan yang ada belum di semen.

Kekuatan lain yang ditemukan adalah tingginya semangat orang tua untuk mengirimkan anak-anaknya ke sekolah. Kesadaran orang tua merupakan sebuah bentuk investasi jangka panjang yang secara tidak langsung akan mendukung pemberdayaan sosial yang akan dilaksanakan. Keyakinan ini berdasarkan pada kepercayaan bahwa pendidikan dapat meningkatkan kualitas hidup generasi muda warga Sonde. Namun demikian hambatan yang tampak adalah kondisi orang tua yang kebanyakan buta huruf dan faktor ini bisa menghambat proses pembelajaran. Selain itu jumlah fasilitas sekolah yang tidak merata juga turut berkontribusi terhadap lambatnya pemberdayaan di bidang pendidikan belum lagi mengenai jumlah pengajar yang kurang.

Selain aspek pendidikan, bangunan fisik berupa rumah juga merupakan salah satu kelemahan yang ada di desa Sonde. Mayoritas dari rumah penduduk adalah tidak layak huni dan untuk membangunnya memerlukan perjalanan yang panjang karena material untuk membangun rumah harus diambil dari desa lain. Mengingat kondisi jalan dan juga transportasi yang harus digunakan, tahapan ini tentunya akan membutuhkan dana yang banyak sementara anggaran yang tersedia terbatas. Selain bahan, pekerja yang mau membangun rumah dengan menjadi kuli juga sangat jarang, penduduk lebih banyak yang menjadi buruh di perikanan atau industri.

Mengacu pada poin-poin yang berhasil dirangkum dalam analisis SWOT, maka terdapat empat aspek yang menjadi prioritas pemberdayaan, yaitu penataan pemukiman dan perumahan, pemberdayaan sumber daya manusia, pemberdayaan lingkungan, dan pemberdayaan ekonomi produktif. 


\section{Simpulan dan Saran}

Desa Sonde memiliki potensi sumber daya alam dan manusia yang cukup memadai yaitu demografi penduduk dalam usia produktif serta tanah pertanian yang cukup luas dalam bentuk tanah belukar. Tantangannya adalah terwujudnya prioritas pemberdayan lingkungan, pemberdayaan sumber daya manusia, pemberdayaan ekonomi produktif serta penataan perumahan dan pemukiman. Analisis Swot digunakan untuk dijadikan sebuah proses dalam strategi persiapan pemberdayaan di Desa Sonde, sehingga sinergitas lintas sektor dalam setiap tahapan persiapan sehingga ditemukan prioritas pemberdayaan, dan alternative solusi bagi permaslahan tersebut.

\section{Daftar Rujukan}

Anggreswari, N. P. Y., \& Jayaningsih, A. A. R. (2018). Pemberdayaan Masyarakat Melalui Pengembangan Objek Wisata Hidden Canyon Beji Guwang. Jurnal Ilmiah Ilmu Sosial, 4(1), 3040. https://doi.org/10.23887/jiis.v4i1.13952

Batangan, Dennis, et al. 2007. The Road To Empowerment: Strengthening the Indigenous peoples Rights Act. Volume 2: Nurturing the earth, nurturing life:ILO Office : Manila.

Campbell, Matthew., Christie, Michael. 2008. Indigenous Community Engagement @ Charles Darwin University. https://www.cdu.edu.au/centres/spill/pdf/ICE@CDU FINAL.pdf.

Cornwall, A. and Jewkes, R. (1995) 'What is participatory research?', Social Science and Medicine, vol 41, no 12, pp1667-1676.

Hasbullah, H. (2018). Kehidupan Keberagamaan Masyarakat Suku Akit di Desa Sonde Kabupaten Kepulauan Meranti. Sosial Budaya, 15(1), 1. https://doi.org/10.24014/sb.v15i1.5734

Marwanti, S., \& Astuti, I. (2012). Model Pemberdayaan Perempuan Miskin Melalui Pengembangan Kewirausahaan Keluarga Menuju Ekonomi Kreatif Di Kabupaten Karanganyar. Sepa, 9(1), 134-144.

Rahim, M., Tahir, M., \& Rumbia, W. A. (2014). Model Pemberdayaan Masyarakat di Wilayah Pesisir dalam Menanggulangi Kemiskinan di Kabupaten Buton, Sulawesi Tenggara. The Winners, 15(1), 23. https://doi.org/10.21512/tw.v15i1.633

Sidiq, R. S. S., \& Sulistyani, A. (2017). Peluang Dan Tantangan Program Pemberdayaan Komunitas Adat Terpencil (Kat) Di Desa Sungai Upih Provinsi Riau (Opportunities and Challenges on the Empowerment Program of Remote Indigenous Community in Sungai Upih Village Riau Province). Asian Journal of Environment, History and Heritage, 1(December), 29-38.

Sonde Village Profile year 2013 